\title{
Essential Oil Composition of Thyme (Thymus zygioides Griseb. var. lycaonicus (Celak.) Ronniger) Wild Growing in Turkey
}

\author{
Erman Duman ${ }^{1, a, *}$, Mehmet Musa Özcan²,b, Zrira Saadia ${ }^{3, c}$, Mustafa Mete Özcan $^{3, d}$ \\ ${ }^{I}$ Food Engineering Department, Engineering Faculty, Afyon Kocatepe University, 03200 Centrum/Afyonkarahisar, Turkey \\ ${ }^{1}$ Department of Food Engineering, Faculty of Agriculture, Selçuk University, 42031 Konya, Turkey \\ ${ }^{2}$ Departement des Sciences Alimentaires et Nutritionnelles, IAV Hassan II BP 6202, Rabat Instituts, Rabat, Morocco \\ ${ }^{3}$ Department of Veterinary Laboratory, Aydoğanlar Karapınar High Vocational College, Selçuk University, 42400 Karapınar/Konya, Turkey \\ *Corresponding author

\begin{tabular}{l|l}
\hline A R T I C L E I N F O & A B S T R A C T \\
\hline Research Article & $\begin{array}{l}\text { The chemical composition of essential oil, which is isolated by hydrodistillation of aerial parts of } \\
\text { Thymus zygioides growing wild in Turkey, have been determined by GC and GC/MS. Essential oil } \\
\text { yield on a dry weight basis of aerial parts from T. zygioides was } 0.45 \% . \text { A total of twenty two } \\
\text { constituents were identified by GC-MS analyses, the main components representing 92.3\% the oil } \\
\text { was identified as limonene (24.11\%), cis-linalool oxide }(22.91 \%), \text { eucalyptol }(8.65 \%) .3-0 c t o n o l \\
\text { Accepted : } 29 / 11 / 2019\end{array}$ \\
$\begin{array}{l}(7.04 \%), \text { nerol }(4.47 \%) \text { geranyl acetate }(3.19 \%), \text { carvacrol }(2.74 \%), \text { linalyl propanoate }(2.95 \%) \text { and } \\
\text { sabinene (2.23\%). The essential oil of } T . \text { zygioides was characterized by its high content of limonene } \\
(24.11 \%) .\end{array}$
\end{tabular}

Keywords:

Thymus zygioides

Labiatae

Essential oil composition

Limonene

Cis-linalool oxide

\section{Introduction}

Thyme (Thymus zygioides) is aromatic plants of middle Anatolia basin belonging to the Labiatae family (Davis, 1992). It is a hardy perennial and herbaceous plant which grows wild in its naturel areas. The family labiatae (Lamiaceae) is represented in Turkey by 556 species and 741 taxa (Başer, 1995; Tümen et al., 1998). It is Turkish endemic species commonly used in cooking as spices and condiments, in the preparation of herbal tea and also employed, since antiquity, in folk medicine (Biavati et al., 2004). The volatile aromatic compounds are employed in the food industry as a flavoring agent. The oil is used in perfumery for its spicy herbaceous notes. The plant of genus Thymus and their essential oils are used for their bioactivity (Reddy et al., 1998; Tzakou et al., 1998; Kulevanova et al., 1998; Tikhonov et. al., 1998). The plants and the essential oils have antimicrobial, antifungal, antioxidant, antihelminthic, antitoxic, diuretic and stimulant properties. It is known as tonic and carminative (Baytop, 1984). T. zygioides, named as "yayla kekik", is used as condiment in Konya province. Recently, the essential oils obtained through steam distillation on Thymus pulegioides, T. vulgaris, T. transcaspicus, T. shimperi, T. serrulatus, and T.serpylloides ssp gadorensis were studied, (Hubaid et al., 2002; Asfaw et al., 2000; Saez, 2001; Miri et al., 2002; Mockute and Berrotiene, 2003). Miri et al. (2002) reported that the most abundant components between 47 compounds were thymol, $\gamma$ terpinene, carvacrol, $p$-cymene and thymol methyl ether. This oil has not previously been investigated. In the present study, the chemical composition of essential oil of the airdried parts of the wild plant T.zygioides growing was characterized via GC and GC-MS. 


\section{Material and Method}

\section{Plant Material}

Fresh aerial parts of Thymus zygioides were collected from plants growing wild in Konya (Doğanhisar) provinces of Middle Anatolia (Turkey) and identified at the Department of Biology, Selçuk University, Konya, Turkey (Voucher specimen No: 3553). The aerial parts were dried in the shade at room temperature.

\section{Isolation of the Essential Oil}

Dried aerial parts of the plants (about $100 \mathrm{~g}$ ) were ground and submitted to hydrodistillation for $4 \mathrm{~h}$ using a Clevenger-type apparatus. The oil isolated was dried over anhydrous sodium sulfate. The oil yield of Thymus zygioides on dry weight basis were $0.45 \%$.

\section{Identification of Components}

GC: The analysis was carried out using a DANI 6500 gas chromatograph equipped with FID and a DB-5 capillary column $(30 \mathrm{~m} \times 0.22 \mathrm{~mm}$, film thickness 0.25 $\mu \mathrm{m})$. Analytical conditions were: injector and detector temperature $200^{\circ} \mathrm{C}$ and $220^{\circ} \mathrm{C}$ respectively; oven temperature programmed from $50^{\circ} \mathrm{C}$ to $180^{\circ} \mathrm{C}$ at $4^{\circ} \mathrm{C} / \mathrm{min}$. The carrier gas flow was $1 \mathrm{ml} \mathrm{N}_{2} / \mathrm{min}$. Relative concentrations were calculated using peak areas as given by Shimadzu model CR3A integrator, without correction for response factors. Retention indices were obtained by injection of the homologous hydrocarbon series $\mathrm{C}_{8}-\mathrm{C}_{18}$ under the same conditions.

GC/MS: Analyses were done using an HP 5870 Series II gas chromatograph equipped with a OV-101 capillary column ( $25 \mathrm{~m}$ x $0.18 \mathrm{~mm}$; film thickness $0.25 \mu \mathrm{m})$ and an HP 5772A mass selective detector. Analytical conditions as follows injector and detector temperatures $200^{\circ} \mathrm{C}$ and $220^{\circ} \mathrm{C}$, respectively; oven temperature programmed from $60^{\circ} \mathrm{C}$ to $220^{\circ} \mathrm{C}$ at $4^{\circ} \mathrm{C} / \mathrm{min}$. The carrier gas flow was $1.2 \mathrm{ml}$ $\mathrm{He} / \mathrm{min}$, and the ionization source was set at $70 \mathrm{eV}$.

The essential oil constituents were identified by the combination of retention index data and mass spectra data using NBS library and other literature data.

\section{Results and Discussion}

The volatile oil components of Thymus zygioides collected from different populations in the same locality was determined by GC and GC-MS. The results of analysis are given in Table 1. The oil was subjected to GC and GC/MS analysis, and the components greater than $0.01 \%$ were identified by chromatograph with GC kovats indices and MS data.

The findings in Table 1 show that the oil contained mainly monoterpenes and oxygenated monoterpenoids. In this study, the most prominent components were cislinalool oxide $(22.91 \%)$, limonene $(24.11 \%)$ eucalyptol (8.65\%), 3-octanol (7.04\%), nerol (4.47\%), geranyl acetate $(3.19 \%)$, carvacrol $(2.74 \%)$, linalyl propanoate $(2.95 \%)$ and sabinene $(2.23 \%)$. They formed about $78 \%$ of total essential oil. Investigation of the essential oil of Thymus has shown that the volatile aroma composition is typical to origin of the plant (Akgül et al., 1999; Tümen et al., 1998). Tümen et al. (1998) reported the Thymus aznavourii oil was rich in germacrene D (22.8\%), (E)- $\beta$-farnesene
(16.1\%) and $\alpha$-pinene $(11.1 \%)$. Thymus cilicicus is very rich in $\alpha$-terpineol $(16.4 \%)$, camphor $(9.7 \%)$, $\alpha$-pinene $(6,9 \%), 1.8$-cineole $(7.8 \%)$ and trans-sabinene hydrate $(5,2 \%)$ (Akgül et al., 1999).

Table 1 Chemical composition of high plateau (Thymus zygioides) oil (\%)

\begin{tabular}{l|lc}
\hline \multicolumn{1}{c|}{ RI } & \multicolumn{1}{c}{ Constituents } & Percentage \\
\hline 934 & $\alpha$-pinene & 0.55 \\
950 & Camphene & 1.23 \\
971 & Sabinene & 2.23 \\
975 & 1-octen-3-ol & 0.46 \\
982 & $\beta$-myrcene & 0.44 \\
993 & 3-octanol & 7.04 \\
1018 & $\alpha$-terpinene & 1.40 \\
1023 & o-cymene & 0.55 \\
1031 & Limonene & 24.11 \\
1035 & Eucalyptol & 8.65 \\
1056 & $\gamma$-terpinene & 1.07 \\
1070 & Cis-linalool oxide & 22.91 \\
1161 & Borneol & 1.2 \\
1173 & 4-terpineol & 1.86 \\
1314 & Linalyl propanoate & 2.95 \\
1228 & Nerol & 4.47 \\
1241 & neral & 1.08 \\
1256 & Geraniol & 0.76 \\
1207 & Fenchyl acetate & 1.91 \\
1290 & Thymol & 1.50 \\
1298 & Carvacrol & 2.74 \\
1384 & Geranyl acetate & 3.19 \\
\hline Total & & 92.30 \\
\hline
\end{tabular}

The major constituents of Thymus daenensis oil were thymol $(49.7 \%)$, carvacrol $(15.2 \%), p$-cymene $(6.4 \%), \gamma$ terpinene $(5.4 \%)$ and 1,8-cineole + limonene $(3.2 \%)$ (Askari and Setidkon, 2003). p-Cymene (37.44\%), carvacrol (32.22\%), borneol (5.98\%), $\gamma$-terpinene $(5.40 \%)$ and 1,8-cineole $(1.84 \%)$ were found to be the major components in the $T$. sintenisii subsp. isaurica oil (Biavati et al., 2004). The $\alpha$-terpinene (3-8\%), $\gamma$-terpinene (17$30 \%)$, thymol (2-18\%), $p$-cymene (15-20\%), and $\alpha$-thujene (2-4\%) were the main components in Thymus striatus (D'Auria et al. 2005). The presence of high quantities of $\beta$ caryophyllene and (E)-nerolidol in the essential oils was found at least in two species ( $T$. pulegioides L. and $T$. albanus) of genus Thymus (Kulevanova et al., 1998).

A review of the literature reveals that the volatile compounds of this plant have been the subject of previous studies in other geographical areas. The chemical composition of this oil has been known to differ enormously due to different geographical origins. The observed differences may be probably due to different environmental factors, different chemotypes and the nutritional status of the plants as well as other factors that can influence the oil composition. Also, it is well known that environmental conditions and the stage of development can affect the relative amounts of essential oil components (Milos et al., 2001). As a result, our findings indicated that essential oil of $T$. zygioides from Turkey belonged to limonene and Cis-linalool oxide rich type. 


\section{Acknowledgement}

This work was supported by Selçuk Üniversity Scientific Research Project (S.Ü.-BAP, Konya-TURKEY).

\section{References}

Akgül A, Özcan M, Chialva F, Manguzzi F. 1999. Essential oils of four Turkish wild- growing Labiatae herbs: Salvia cryptantha Montbr. et Auch., Satureja cuneifolia Ten., Thymbra spicata L. and Thymus cilicicus Boiss. et Bal. Journal of Essential Oil Research 11, pp: 209-214.

Asfaw N, Storesund HJ, Skattebol L, Tonnesen F, Aasen AJ. 2000. Volatile oil constituents of two Thymus species from Ethiopia. Flavour and Fragrance Journal 15, pp: 123-125.

Askari F, Sefidkon F. 2003. Essential oil composition of Thymus daenensis Celak. from Iran. Journal of Essential Oil-Bearing Plants 6(3), pp: 217-219.

Baytop T. 1984. Treatment with plants in Turkey. İstanbul Univ. Publ. No. 3255, İstanbul. (in Turkish).

Başer KHC. 1995. Flavours, Fragrances and Essential Oils, Proceedings of the 13 th International Congress of Flavours, Fragrances and Essential Oils, Vol.2, p.67.

Biavati B, Özcan M, Piccaglia R. 2004. Composition and antimicrobial properties of Satureja cuneifolia Ten. and Thymbra sintenisii Bornm. et Aznav. Subsp. isaurica P.H. Davis essential oils. Annals of Microbiology 54(4): pp: 393401.

Davis PH. 1982. Flora of Turkey and the East Aegean Islands. Vol. 7, pp 363-365, Univ. Press, Edinburgh.

D'Auria M, Mauriello G, Marino R, Racioppi R. 2005. Composition of volatile fractions from Thymus, Origanum, Lavendula and Acinos species. Journal of Essential Oil Bearing Plant 8(1), pp: 36-51.
Hubaid M, Speroni E, Di Pietra AM, Cavrini V. 2002. GC/MS evaluation of thyme (Thymus vulgaris $\mathrm{L}$.) oil composition and variations during the vegetative cycle. Journal of Pharmaceutical and Biomedical Analysis 29, pp: 691-700.

Kulenova S, Ristic M, Stafilov T, Matevski V. 1998. Composition of the essential oil of Thymus albanus ssp. albanus A. Braun from Macedenia. Journal of Essential Oil Research 10, pp: 335-336.

Milos M, Radonic A, Bezic N, Dunkic CV. 2001. Localities and seasonal variations in the chemical composition of essential oils of Satureja montana L. and S.cuneifolia Ten. Flavour and Fragrance Journal 16, pp: 157-160.

Miri R, Ramezani M, Javidnia K, Ahmadi L. 2002. Composition of the volatile oil of Thymus transcaspicus Klokov from Iran. Flavour and Fragrance Journal 17, pp: 245-246.

Mockute D, Bernotiene G. 2003. Five chemotypes of the essential oils of Thymus pulegioides L. growing wild in Lithuania. Journal of Essential Oil-Bearing Plants 6(3), pp: 139-147.

Reddy MVB, Angers P, Gosselin A, Arul I. 1998. Characterization and use of essential oil from Thymus vulgaris against Botrytis cinerea and Rhizopus stolonifer in strawberry. Phytochemistry 47, pp: 1515-1520.

Saez F. 2001. Volatile oil variability in Thymus serpylloides spp. gadorensis growingwild in Southern Spain. Biochemical Systematics and Ecology 29, pp: 189-198.

Tikhanov VN, Khan VA, Kalinkina GI. 1998. Composition of the essential oils of Thymus krylovii. Khimiya Prirodnikh Soedinengi. pp: 886-887.

Tümen G, Başer KHC, Demirci B, Ermin N. 1998. The essential oils of Satureja coerulea Janka and Thymus aznavourii Velen. Flavour and Fragrance Journal 13,65-67.

Tzakou O, Verykokidou E, Roussis V, Chinou I. 1998. Chemical composition and antibacterial properties of Thymus longicaulis subsp. chaubardi oils three chemotypes in same population. Journal of Essential Oil Research 10, pp: 97-99. 